\title{
CORRIGENDUM
}

\section{Differential susceptibility to effects of maternal sensitivity? A study of candidate plasticity genes-CORRIGENDUM}

\author{
JAY BELSKY, ${ }^{a}$ DANIEL A. NEWMAN, ${ }^{b}$ KEITH F. WIDAMAN ${ }^{c}$ PHIL RODKIN,${ }^{b}$ MICHAEL PLUESS, ${ }^{c}$ \\ R. CHRIS FRALEY, ${ }^{b}$ DANIEL BERRY, ${ }^{b}$ JONATHAN L. HELM, ${ }^{a}$ AND GLENN I. ROISMAN ${ }^{d}$ \\ ${ }^{a}$ University of California, Davis; ${ }^{b}$ University of Illinois at Urbana-Champaign; ${ }^{c}$ Kings College London; and ${ }^{d}$ University \\ of Minnesota
}

doi:10.1017/S0954579414000844, published by Cambridge University Press, 15 September 2014

The regression lines in Figure 1 were incorrectly illustrated. The line denoting the regression of the outcomes on sensitivity for the AA group should have been dark and solid and the regres-

\section{Reference}

Belsky, J., Newman, D. A., Widaman, K. F., Rodkin, P., Pluess, M., Fraley, R. C., et al. (2014). Differential susceptibility to effects of maternal sensitivity? A study of candidate plasticity genes. Development and sion of the outcomes on sensitivity for the AG/GG group should have been blue and hashed. The corrected figure is presented here. We regret this error and any problems it may have caused. 

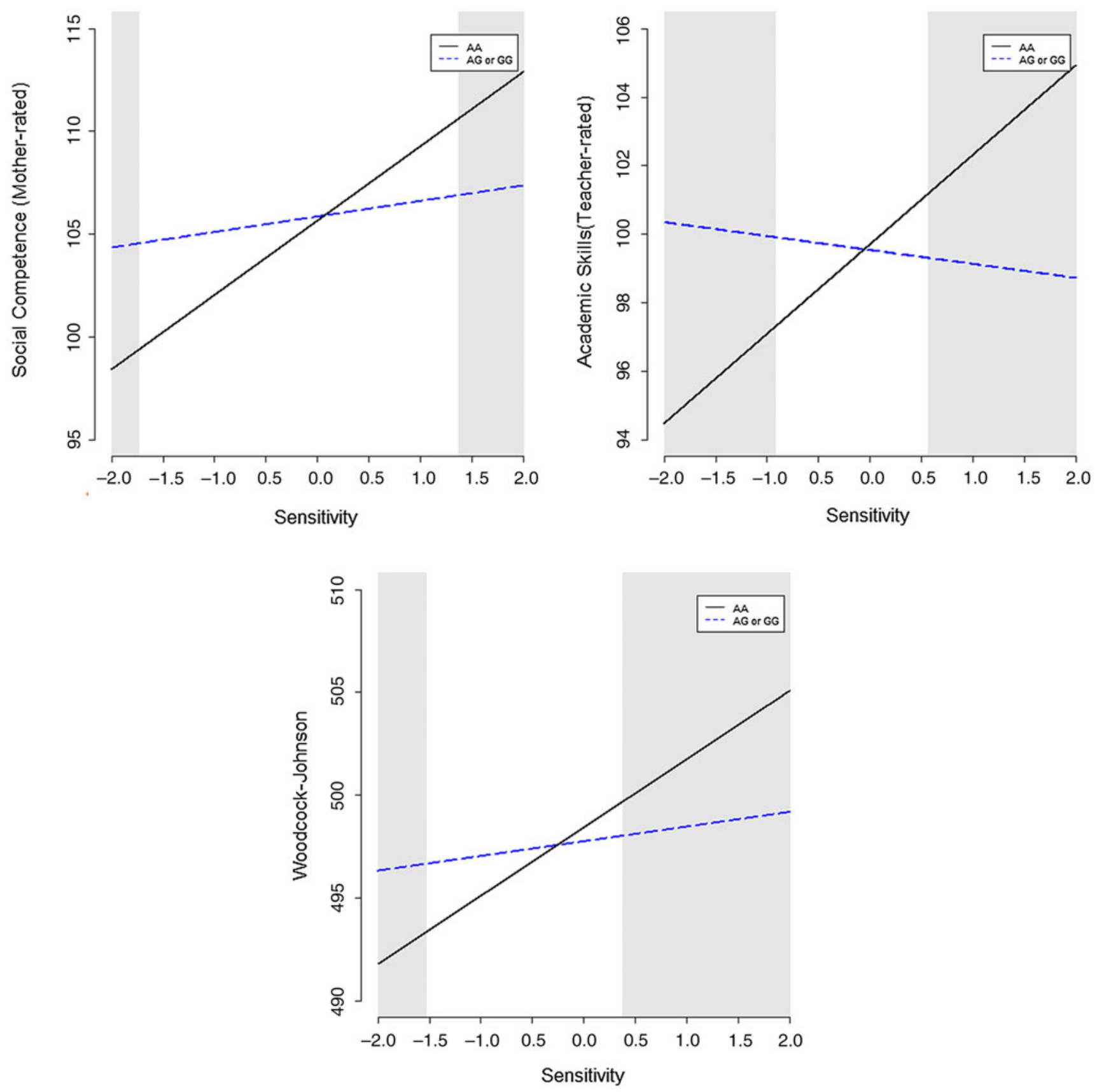

Figure 1. (Color online) Genetic Marker $(O P R M I) \times$ Environment (maternal sensitivity) interactions for mother-rated social competence, teacherrated academic skills, and academic skills as assessed via the Woodcock-Johnson, respectively. The gray regions represent regions of significance. 